\title{
SISTEM PREDIKSI KELAYAKAN BESARAN PINJAMAN PEMBERIAN KREDIT PENSIUNAN DENGAN MENGGUNAKAN FUZZY LOGIC (STUDI KASUS: PT. BANK BUKOPIN)
}

\author{
M YASSER ARAFAT, RACHMAT SEPTI MEZUL \\ Teknik Informatika Universitas Pamulang \\ J1. Surya Kencana No. 1, Pamulang, Tangerang Selatan-Indonesia \\ E-mail : dosen00680@Unpam,ac.id
}

\begin{abstract}
ABSTRAK
Kredit adalah penyediaan uang atau tagihan-tagihan yang dapat disamakan dengan itu berdasarkan persetujuan pinjam-meminjam antara bank dengan pihak lain dalam hal mana pihak peminjam berkewajiban melunasi utangnya setelah jangka waktu tertentu dengan bunga yang telah ditetapkan (Jayanti, 2014). Masalah kelayakan pemberian kredit cenderung bersifat samar (fuzzy) (Ariana \& Suwadnyana, 2013), dimana untuk menentukan kelayakan besaran pinjaman tidak dapat ditentukan dengan mudah dan cepat, serta membutuhkan tenaga ahli. Kelayakan besaran pinjaman perlu dianalisa ataupun diprediksi (Misdiati \& Rahayu, 2013), karena besarnya pinjaman merupakan salah satu penyebab utama kredit macet walaupun sebagian terbesar kredit macet diakibatkan salah dalam mengadakan analisis. Logika fuzzy (fuzzy logic) dapat digunakan untuk memodelkan suatu permasalahan yang matematis, dimana konsep matematis yang mendasari penalaran Fuzzy sangat sederhana dan mudah dimengerti, Logika fuzzy (fuzzylogic) adalah suatu metode atau cara yang tepat untuk memetakan kesuatu ruang input ke suatu ruang output (Widodo \& Handayanto, 2012).
\end{abstract}

Kata kunci : Besar Pinjaman, Kredit, Fuzzy Logic

\section{PENDAHULUAN}

Kemajuan Kredit adalah penyediaan uang atau tagihan-tagihan yang dapat disamakan dengan itu berdasarkan persetujuan pinjammeminjam antara bank dengan pihak lain dalam hal mana pihak peminjam berkewajiban melunasi utangnya setelah jangka waktu tertentu dengan bunga yang telah ditetapkan (Jayanti, 2014). Masalah kelayakan pemberian kredit cenderung bersifat samar (fuzzy) (Ariana \& Suwadnyana, 2013), dimana untuk menentukan kelayakan besaran pinjaman tidak dapat ditentukan dengan mudah dan cepat, serta membutuhkan tenaga ahli. Kelayakan besaran pinjaman perlu dianalisa ataupun diprediksi (Misdiati \& Rahayu, 2013), karena besarnya pinjaman merupakan salah satu penyebab utama kredit macet walaupun sebagian terbesar kredit macet diakibatkan salah dalam mengadakan analisis.

Pada saat ini, sebagai salah satu lembaga keuangan yang terus berkembang PT. Bank BUKOPIN memiliki program untuk pemberian kredit pensiunan kepada pegawai negeri sipil, pensiunan BUMN, POLRI dan TNI, akan tetapi saat ini belum adanya sistem komputerisasi yang digunakan untuk menganalisa atau memprediksi kelayakan besarnya pinjaman pemberian kredit pensiunan yang diajukan nasabah, selama ini dilakukan oleh seorang analis keuangan hal ini menyebabkan proses analisa atau perhitungan kelayakan besarnya pinjaman pemberian kredit pensiunan yang diajukan nasabah membutuhkan waktu yang lama.

Metode yang biasa digunakan untuk melakukan prediksi perkreditan adalah Metode Weighted Product (Jayanti, 2014), newton truncated-kernel logistic regression (Misdiati \& Rahayu, 2013) dan Fuzzy Inference system metode mamdani (Ariana \& Suwadnyana, 2013). Logika fuzzy (fuzzy logic) dapat digunakan untuk memodelkan suatu permasalahan yang matematis, dimana konsep matematis yang mendasari penalaran Fuzzy sangat sederhana dan mudah dimengerti, Logika fuzzy (fuzzy logic) adalah suatu metode atau cara yang tepat untuk memetakan kesuatu ruang input ke suatu ruang output (Widodo \& Handayanto, 2012).

Logika fuzzy (fuzzy logic) merupakan metode yang memiliki kelebihan sebagai berikut (Kusumadewi \& Purnomo, 2010) :

a. Konsep Logika fuzzy (fuzzy logic) mudah dimengerti. Konsep matematis yang 
mendasari penalaran fuzzy sangat sederhana dan mudah dimengerti.

b. Logika fuzzy (fuzzy logic) sangat fleksibel.

c. Logika fuzzy (fuzzy logic) memiliki toleransi terhadap data-data yang tidak tepat.

d. Logika fuzzy (fuzzy logic) mampu memodelkan fungsi-fungsi nonlinear yang sangat kompleks.

e. Logika fuzzy (fuzzy logic) dapat membangun dan mengaplikasikan pengalamanpengalaman pakar secara langsung tanpa harus melalui proses penelitian.

f. Logika fuzzy (fuzzy logic) dapat bekerja sama dengan teknik-teknik kendali secara konvensional.

Pada penelitian ini penulis akan merancang dan membangun sistem prediksi kelayakan besaran pinjaman pemberian kredit pensiunan dengan menerapkan fuzzy logic, agar proses analisa atau perhitungankelayakan besarnya pinjaman pemberian kredit pensiunan yang diajukan nasabah menjadi lebih cepat.

\section{METODE PENELITIAN}

Sistem penunjang keputusan (Decision Support Sistem) merupakan suatu istilah yang mengacu pada suatu sistem yang memamfaatkan dukungan komputer dalam proses pengambilan keputusan. Untuk memberikan pengertian tersebut, disini akan diuraikan definisi mengenai Sistem Pendukung Keputusan yaitu SPK. SPK merupakan suatu sistem yang interaktif, yang membantu pengambil keputusan melalui penggunaan data dan model-model keputusan untuk memecahkan masalah yang sifatnya semi terstruktur maupun yang tidak terstruktur.

SPK atau Decission Support Sistem (DSS) merupakan suatu kumpulan sistem yang dapat mendukung proses pengambilan keputusan, yang selanjutnya dapat menunjang pengambilan keputusan dalam memperoleh data dan menguji beberapa alternatif-alternatif solusi yang mengandung konsekuensi-konsekuensi selama proses pemecahan masalah berlangsung atau boleh disebut merupakan aplikasi dari sebuah sistem informasi yang membantu proses pengambilan keputusan.

SPK tidak ditekankan untuk membuat keputusan, tetapi untuk melengkapi mereka yang terlibat dalam pengambilan keputusan dengan sekumpulan kemampuan untuk mengolah informasi yang diperlukan dalam proses pengambilan keputusan dan sistem ini bukan dimaksudkan untuk mengganti pengambilan keputusan dalam membuat suatu keputusan, melainkan mendukung pengambil keputusan.

Logika fuzzy (fuzzy logic) dapat digunakan untuk memodelkan suatu permasalahan yang matematis, dimana konsep matematis yang mendasari penalaran Fuzzy sangat sederhana dan mudah dimengerti. Logika fuzzy (fuzzy logic) merupakan generalisasi dari logika klasik (CrispSet) yang hanya memiliki dua nilai keanggotaan yaitu 0 dan 1. Dalam Logika fuzzy (fuzzy logic) nilai kebenaran suatu pernyataan berkisar dari sepenuhnya benar sampai dengan sepenuhnya salah. Fuzzy logic berhubungan dengan ketidakpastian yang telah menjadi sifat alamiah manusia, mensimulasikan proses pertimbangan normal manusia dengan jalan memungkinkan komputer untuk berperilaku sedikit lebih seksama dan logis daripada yang dibutuhkan metode komputer konvensional.

Pemikiran dibalik pendekatan ini adalah pengambilan keputusan tidak sekadar persoalan hitam dan putih atau benar dan salah, namun kerapkali melibatkan area abu-abu, dan hal itu dimungkinkan. Seiring dengan perkembangan zaman, pada tahun 1974 ilmu ini mulai mememukan aplikasinya pada bidang kontrol, dan Mamdani memperkenalkan aplikasi Fuzzy sebagai alat kontrol steam-engine. Hal ini merupakan momentum penting, sebagai awal bagi teknologi Fuzzy untuk menemukan ladang aplikasi di dunia industry.

Fuzzy merupakan representasi suatu pengetahuan yang dikonstruksikan dengan Ifthen rules.

\section{PEMBAHASAN}

Analisa sistem informasiakan membantu dalam mengetahui informasi-informasi tentang sistem yang sedang berjalan. Sehingga dengan analisa sistem, diharapkan bisa diketahui sejauh mana peranan sistem yang tengah berjalan dalam memenuhi kebutuhan perusahaan, agar kebutuhan-kebutuhan yang belum bisa terpenuhi dapat diberikan solusinya dan diterapkan dalam tahap perancangan sistem.

Pada tahapan ini, dilakukan proses pemberian aturan Fuzzy kedalam sistem.

Dengan Penjelasan sebagai berikut:

1. If Usia is Paruh baya and Lama Kerja is Sebentar and Dana Pensiun is Kecil then besar pinjaman is Kecil.

2. If Usia is Paruh baya and Lama Kerja is Sebentar and Dana Pensiun is Sedang then besar pinjaman is Kecil. 
3. If Usia is Paruh baya and Lama Kerja is Sebentar and Dana Pensiun is Besar then besar pinjaman is Sedang.

4. If Usia is Paruh baya and Lama Kerja is Cukup and Dana Pensiun is Kecil then besar pinjaman is Kecil.

5. If Usia is Paruh baya and Lama Kerja is Cukup and Dana Pensiun is Sedang then besar pinjaman is Sedang.

6. If Usia is Paruh baya and Lama Kerja is Cukup and Dana Pensiun is Besar then besar pinjaman is Sedang.

7. If Usia is Paruh baya and Lama Kerja is Lama and Dana Pensiun is Kecil then besar pinjaman is Sedang.

8. If Usia is Paruh baya and Lama Kerja is Lama and Dana Pensiun is Sedang then besar pinjaman is Besar.

9. If Usia is Paruh baya and Lama Kerja is Lama and Dana Pensiun is Besar then besar pinjaman is Besar.

10. If Usia is Tua and Lama Kerja is Sebentar and Dana Pensiun is Kecil then besar pinjaman is Kecil.

11. If Usia is Tua and Lama Kerja is Sebentar and Dana Pensiun is Sedang then besar pinjaman is Kecil.

12. If Usia is Tua and Lama Kerja is Sebentar and Dana Pensiun is Besar then besar pinjaman is Sedang.

13. If Usia is Tua and Lama Kerja is Cukup and Dana Pensiun is Kecil then besar pinjaman is Kecil.

14. If Usia is Tua and Lama Kerja is Cukup and Dana Pensiun is Sedang then besar pinjaman is Sedang.

15. If Usia is Tua and Lama Kerja is Cukup and Dana Pensiun is Besar then besar pinjaman is Besar.

16. If Usia is Tua and Lama Kerja is Lama and Dana Pensiun is Kecil then besar pinjaman is Sedang.

17. If Usia is Tua and Lama Kerja is Lama and Dana Pensiun is Sedang then besar pinjaman is Besar.

18. If Usia is Tua and Lama Kerja is Lama and Dana Pensiun is Besar then besar pinjaman is Besar.

\section{KESIMPULAN}

Berdasarkan implementasi dan pengujian sistem yang telah dilakukan, maka dapat ditarik kesimpulan sebagai berikut: a. Fuzzy logic dapat diterapkan pada prediksi kelayakan besaran pinjaman pemberian kredit pensiunan.

b. Dengan menerapkan Fuzzy logic dapat mempercepat proses analisa ataupun penaksiran kelayakan besarnya pinjaman yang diajukan nasabah.

\section{DAFTAR PUSTAKA}

[1] Ariana, G. B., \& Suwadnyana , I. B. (2013). Fuzzy inference sistem mamdani untuk penentuan kredit pada KPN Estika Dewata. Jurnal Nasional Pendidikan Teknik Informatika (JANAPATI), 153-163.

[2] Hidayat, A. (2011). sistem penunjang keputusan untuk pemilihan karyawan teladan dengan logika fuzzy tsukamoto (studi kasus : pt. fif (federal international finance)). Banjarmasin: Program Studi Teknik Informatika Sekolah Tinggi Manajemen Informatika \& Komputer Banjarbaru (STMIK Banjar Baru).

[3] Kusumadewi, S., \& Purnomo, H. (2010). Aplikasi Logika Fuzzy. Yogyakarta: Graha Ilmu

[4] Sugiharto, A. (2006). Pemgraman GUI dengan Matlab. Yogyakarta: C.V Andi Offset (Penerbit Andi).

[5] Welling, L., \& Thomson, L. (2001). PHP and MySQL Web Development. United States: Sams. 